\title{
The Effect of Parents of The Parents on The Cooperative Level of Children Age 3-5 Years of Care Dental and Mouth in Blang Karieng Village District Nisam
}

\author{
Suriani $^{1}$, Rahmad Al-Hidayat ${ }^{2}$ \\ ${ }^{1,2}$ Getsempena STIKes Lhoksukon North Aceh Regency
}

\begin{abstract}
The problem of management of child behavior is a major problem in the practice of pediatric dentistry. One of the factors that influence the child's response to dental and oral care is parenting. In general, parenting is divided into three main categories, namely authoritarian parenting, permissive and democratic. The purpose of this study was to study the effect of parenting on the cooperative level of children aged 3-5 years in dental and oral care. This study was an analytic observational study with a cross sectional research design. Population is the total number of subjects studied. The population in this study were all children aged 3-5 years in Blang Karieng Village, which numbered 36 children. Sampling was carried out using total sampling techniques totaling 35. This study was from April 2018, using a questionnaire as a research instrument. The results showed that simultaneously there was a significant effect of the independent variables on the dependent variable with a value of $\operatorname{sig}<\alpha(0.05)$. While partially the most influential variables on child cooperatives are authoritarian and permissible variables with a p-value of 0.085 . The conclusion of this study, it can be concluded that there is a significant effect of parenting on the cooperative level of children aged 3-5 years in dental and oral care.
\end{abstract}

Keyword: Parenting, Cooperative Level.

Received 04 February 2019 | Revised 14 May 2019| Accepted 26 January 2019

\section{Introduction}

Children are the most beautiful gifts and the mandate given by Allah SWT to every parent. Every parent will feel happy if they get a healthy, funny and adorable child. Children are assets and can also determine the throne of their parents in the hereafter, but this one property cannot be cashed or traded, because the child is the soulmate of each parent (Soeparmin, 2014).

According to Khairani (2011), the developmental stage often times children experience many problems or obstacles, especially at school age (6-12 years). That period is the time when the child adapts from the preschool period (0-6 years) who are accustomed to meeting or playing

*Corresponding author at: 2Getsempena STIKes Lhoksukon North Aceh Regency

E-mail address: suriani122@gmail.com 
with the house people, especially parents, to the period where he will meet or play with his new friend. Do not rule out the possibility at that time is the time when children are easily influenced by the environment.

Personality characteristics are considered as the things that most influence children's behavior, besides that it is also strongly influenced by the social and family environment. The influence of personality factors such as temperament, general fear and behavioral problems has been extensively studied, but the influence of environmental and situational factors is still relatively under-researched and mostly carried out in Europe and Southeast Asia (Supraba, 2011).

It is at this time that the role of parents is very emphasized. This is also justified by Pramawaty \& Hartati (2012) who said that the inadequacy of the role of parents can have long-term consequences on children's development.

Parenting is one of the most important factors in the formation of the development of children's independence, especially in maintaining cleanliness of themselves (Hardiani et al, 2012). Parenting, raising, educating and caring for children is a noble task that has never escaped various obstacles. No matter how difficult the obstacles are, parents still have to implement them, because this noble task is mandatory.

One example of the business of parents in caring for children is in caring for their children's teeth and mouth health. The problem that is often encountered in this case is the lack of cooperation in carrying out dental and oral care. The lack of cooperation of children in performing dental and oral care problems can be due to several factors including fear, past experience in carrying out general medical care and dental care, the influence of parents or friends, and environmental factors such as the dentist's practice room, doctor's appearance and communication dental or dental nurse (Yusuf, 2013).

Soeparmin (2014) quotes from Wright (1973) that children's behavior is classified into two, namely cooperative and non-cooperative. Children who are categorized as cooperatives are children who have the enthusiasm in doing dental and oral care, while children who are categorized as uncooperative are children who are not or difficult to work with in doing dental and oral care. Non-cooperative types are divided into three categories, which are not able to be cooperative, have not been able to be cooperative and have the potential to be cooperative.

According to Yusuf (2013) the cooperative level of children is influenced by several factors, namely age, gender, mental development, dental history, children's psychological condition, practice environment and parenting style. Handayani \& Puspitasari's (2008) study states that children who have the support of both parents are cooperative when treated at the hospital.

Good parenting will shape positive children's behavior. Likewise, vice versa, hard parenting will shape children's behavior to be irritable, aggressive and easily anxious (Yanuarita, 2014). One manifestation of anxiety in care is the non-cooperation of the child, so that the child refuses to take care (Suprabhra, 2011). Research conducted by Handayani \& Puspitasari (2008) states that 
pediatric patients show very uncooperative behavior if treatment measures are taken, so that collaboration with parents is needed to control children's behavior.

The reaction to dental care in children aged 3-5 years is usually perceived as punishment, so there is a feeling of shame and fear that causes an aggressive, angry, rebellious reaction even some of them will refuse treatment and openly cry do not want to be treated. If the child is very frightened, the child can display biting behavior, kicking and running out of the room. In addition, the child will also cry, confused, especially if the blood comes out or has pain in the limbs (Syahreni, 2011).

The American Academy of Pediatric Dentistry in 2012 acknowledged that children under five vary greatly in their cognitive and emotional development, medical conditions, responses to pain and intervention. Children may be able to assume that pain is a threat in dental care and mouth, especially in children who first undergo the procedure. Bad dentist handling of children at this age can lead to a poor understanding of the child towards dental care so that it can cause the risk of dentalphobia in children.

Psychological conditions and development of children are actually far more understood by their parents than nurses, except that people often do not realize that they have developed an interactive dynamic with children which can sometimes hamper the dentist's efforts to achieve the treatment he wants to do. Many parents think that the problem of handling a child's dental and oral health is only the dentist's full responsibility. Based on the present descriptions, this study was designed to determine the relationship between parents' parenting style and family characteristics of children's behavior in dental care and mouth in the group of preschoolers (3-5 years) (Afriani, 2012).

\section{Problems}

Based on the background of the above problems, the formulation of the problem in this study is whether there is an influence of parenting with the cooperative level of children aged 3-5 years in dental and oral care in the Blang Karieng village of Nisam District.

\section{Research Purposes}

\section{General Purpose}

The general objective of this study was to identify the effect of parenting on the cooperative level of children aged 3-5 years in dental and oral care in the Blang Karieng Village of Nisam District.

\section{Special Purpose}

a. To identify the influence of authoritarian parenting parents on the cooperative level of children aged 3-5 years in dental and oral care. 
b. To identify the influence of permissive parenting parents on the cooperative level of children aged 3-5 years in dental and oral care.

c. To identify the influence of democratic parenting parents on the cooperative level of children aged 3-5 years in dental and oral care.

\section{Benefits of Research}

\section{For Getempena STIKes Lhoksukon Institution}

Can add references in the library about the influence of parenting parents on cooperative levels of children in dental and oral care.

\section{For Parents}

This research is useful as information material about the influence of parenting applied to the behavior of children in dental care so that they are expected to be able to apply the right parenting style to their children.

\section{For nurses}

This study is useful to provide knowledge about the importance of the relationship between parents' attitudes and parenting toward children's behavior in dental and oral care so that they can assist them in anticipating and planning appropriate care for children in order to obtain maximum treatment results.

\section{For researchers}

This research provides a valuable experience in broadening insights and knowledge in the field of research and knowledge in connection with the title of this research.

\section{For further researchers}

This research is expected to be useful for researchers who take the same title.

\section{Research Methods}

This study uses descriptive method with a type of study of correlation (correlation study), with a cross sectional approach, namely research or review of the relationship between two variables in a situation or group of subjects by means of approach, observation or data collection at a time (point time approach). That is, each research subject is only one-time observation and measurements are made on one character or subject variable at the time of examination 


\section{Place and time of research}

This research was conducted in Blang Karieng Village, Nisam District. The time of this research was conducted in April 2018.

\section{Study Population}

Population is the total number of subjects studied. The population in this study were all children aged 3-5 years in Blang Karieng Village, which numbered 36 children.

\section{Research Sample}

The number of samples studied were all children aged 3-5 years in the village of Blang Karing Kecamtang Nisam. The sampling procedure is by using a total sampling technique, which is by taking samples of all children in the village of Blang Karieng, 3-5 years old.

The demographic characteristics of the respondents consisted of gender, age, marital status, recent education, occupation, duration of chronic kidney failure, frequency of hemodialysis every week, and involvement of family or closest people during hemodialysis. The results of this study were that respondents with male sex were more than women, that is, 62 people $(58.5 \%)$, the age range of the respondents was mostly between the ages of 41-60 years, that is, 73 people (68.9\%), the majority of respondents have married as many as 99 people (93.4\%), the last education of the respondents was mostly at the high school level, 47 people (44.3\%), more than half of the respondents did not work, 66 people $(62.3 \%)$, the majority of respondents have suffered chronic kidney failure $\geq 1$ year, that is, 95 people $(50 \%)$, all respondents did $2 \mathrm{x}$ hemodialysis per week, that is, 105 people (99.1\%), and 62 respondents (58.5\%) accompanied by family or closest people while undergoing hemodialysis.

\section{Research Result}

\section{A. Univariate Analysis}

1. Characteristics of Respondents

Tabel 1. Frequency Distribution of Respondents by Gender in Blang Karing Kecamatang Nisam Village in 2017.

\begin{tabular}{|c|l|c|c|}
\hline No & \multicolumn{1}{|c|}{ Gender } & F & \% \\
\hline 1 & Male & 12 & 33,3 \\
\hline 2 & Women & 24 & 66,7 \\
\hline & Amount of & $\mathbf{3 6}$ & $\mathbf{1 0 0 \%}$ \\
\hline
\end{tabular}

Based on the table above it can be seen that the distribution of the most respondents is girls, amounting to 24 people $(66.7 \%)$, and boys totaling 12 people $(33.3 \%)$. 
Tabel 2. Age Distribution of Respondents by Age in Blang Village Karing Kecamatang Nisam In 2017

\begin{tabular}{|c|l|c|c|}
\hline No & \multicolumn{1}{|c|}{ Age } & F & \% \\
\hline 1 & 3 years & 8 & $22,2 \%$ \\
\hline 2 & 4 years & 15 & $41,7 \%$ \\
\hline 3 & 5 years & 13 & 36,1 \\
\hline & Amount of & $\mathbf{3 6}$ & $\mathbf{1 0 0 \%}$ \\
\hline
\end{tabular}

Based on the table above it can be seen that the distribution of respondents based on the age of the most is children aged 4 years, amounting to 15 respondents $(41.7 \%)$.

2. Parenting Parents

a. Democratic Parenting

Table 3. Frequency Distribution of Democratic Foster Patterns in Blang Karieng Village In 2017

\begin{tabular}{|c|c|c|c|}
\hline No & $\begin{array}{l}\text { Democratic Fostering } \\
\text { Pattern }\end{array}$ & F & \% \\
\hline 1 & Democratic & 27 & $75 \%$ \\
2 & Not Democratic & 9 & $25 \%$ \\
\hline & Total & $\mathbf{3 6}$ & $\mathbf{1 0 0 \%}$ \\
\hline
\end{tabular}

Based on the table above, it can be seen that the frequency distribution of democratic parenting toward the cooperative level of children is at most in the democratic category, amounting to 27 respondents (75\%) and non-democratic ones, 9 respondents (25\%).

b. Authoritarian Parenting

Table 4. Frequency Distribution of Authoritarian Care Patterns in Blang Karieng Village In 2017

\begin{tabular}{|c|c|c|c|}
\hline No & $\begin{array}{c}\text { Authoritarian } \\
\text { Parenting }\end{array}$ & F & \% \\
\hline 1 & Authoritarian & 26 & $72,2 \%$ \\
2 & Not Authoritarian & 9 & $27,8 \%$ \\
\hline & Total & $\mathbf{3 6}$ & $\mathbf{1 0 0 \%}$ \\
\hline
\end{tabular}

Based on the table above, it can be seen that the frequency distribution of authoritarian parenting to the cooperative level of children is at most in the authoritarian category, amounting to 27 respondents (72.2\%) and the non-authoritarian ones totaling 9 respondents $(27.8 \%)$. 
c. Permissive Parenting

Table 5. Frequency Distribution of Permissive Care Patterns in Blang Karieng Village In 2017

\begin{tabular}{|c|l|c|c|}
\hline No & Pola Asuh Permisif & F & \% \\
\hline 1 & Permissive & 26 & $72,2 \%$ \\
2 & Not Permissive & 10 & $27,8 \%$ \\
\hline \multicolumn{2}{|c|}{ Total } & $\mathbf{3 6}$ & $\mathbf{1 0 0 \%}$ \\
\hline
\end{tabular}

Based on the table above, it can be seen that the frequency distribution of permissive parenting to the cooperative level of children is at most in the permissive category, which amounts to 27 respondents $(72.2 \%)$ and the non-permissive ones are 9 respondents $(27.8 \%)$.

d. Cooperative Level of Children

Table 6. Frequency Distribution of Cooperative Level Categories of Children in Blang Karieng Village In 2017

\begin{tabular}{|c|c|c|c|}
\hline No & $\begin{array}{l}\text { Cooperative Level of } \\
\text { Children }\end{array}$ & $\mathbf{F}$ & $\%$ \\
\hline 1 & Good & 23 & $63,9 \%$ \\
\hline \multirow[t]{3}{*}{2} & Pretty good & 13 & $36,1 \%$ \\
\hline & Not good & 0 & $0 \%$ \\
\hline & Total & 36 & $100 \%$ \\
\hline
\end{tabular}

Based on the table above, it can be seen that the frequency distribution of the cooperative level of many children is in the good category, amounting to 23 respondents $(63.9 \%)$ and a fairly good number of 13 respondents (36.1\%).

\section{B. Bivariate Analysis}

Furthermore, based on these results bivariate analysis was performed to see the effect of parenting on the cooperative level of children aged 3-5 years in dental and oral care. In detail can be explained as follows:

Table 7. The Effect of Democratic Care Patterns on the Cooperative Level of 3-5 Years Old Children in Dental and Oral Care in Blang Karieng Village, Nisam District, 2017.

\begin{tabular}{|c|c|c|c|c|c|c|c|c|}
\hline \multirow{3}{*}{$\begin{array}{c}\text { Democratic } \\
\text { Parenting }\end{array}$} & \multicolumn{4}{|c|}{$\begin{array}{c}\text { Cooperative level of } \\
\text { Children }\end{array}$} & \multicolumn{2}{|c|}{ Total } & \multirow{2}{*}{$\begin{array}{c}\text { Value } \\
\alpha\end{array}$} & \multirow[t]{2}{*}{$p$ value } \\
\hline & Pre & good & & & & & & \\
\hline & f & $\%$ & f & $\%$ & f & $\%$ & & \\
\hline
\end{tabular}




\begin{tabular}{|c|c|c|c|c|c|c|c|c|}
\hline $\begin{array}{c}\text { Not } \\
\text { Democratic }\end{array}$ & 5 & 13,9 & 4 & 11,1 & 9 & 25 & & \multirow{2}{*}{0,05} \\
\cline { 1 - 5 } Democratic & 8 & 22,2 & 19 & 52,8 & 27 & 75 & & \\
\hline Total & 13 & 36,1 & 23 & 63,9 & 36 & 100 & & \\
\hline
\end{tabular}

Based on the table it is known that out of 9 respondents who were not Democratic in parenting had a fairly good cooperative level of children amounting to $5(13.9 \%)$ and $4(11.1 \%)$ respondents who had good cooperative levels of children. While 27 (75\%) respondents who are quite good at parenting Democracy who have a pretty good level of cooperation amounted to 8 respondents $(22.2 \%)$ and $19(52.8 \%)$ respondents who have a good cooperative level. The statistical test results obtained that the p-value $0.067>0.05$ so that the null hypothesis $(\mathrm{Ho})$ is accepted which means there is an influence of Democratic parenting on the cooperative level of 305-year-old children in dental and oral care in Blang Karieng Village Nisam District 2017.

Table 8. Effect of Authoritarian Parenting on the Cooperative Level of 3-5 Years Old Children in Dental and Oral Care in Blang Karieng Village, Nisam District, 2017.

\begin{tabular}{|c|c|c|c|c|c|c|c|c|}
\hline \multirow{3}{*}{$\begin{array}{c}\text { Authoritarian } \\
\text { Parenting }\end{array}$} & \multicolumn{4}{|c|}{ Cooperative level of Children } & \multicolumn{2}{|c|}{ Total } & \multirow{3}{*}{$\begin{array}{c}\text { Va } \\
\text { lue } \\
\alpha\end{array}$} & \multirow{3}{*}{$\begin{array}{c}p \\
\text { value }\end{array}$} \\
\hline & \multicolumn{2}{|c|}{ Pretty good } & \multicolumn{2}{|c|}{ Good } & & & & \\
\hline & $\mathbf{f}$ & $\%$ & $\mathbf{f}$ & $\%$ & f & $\%$ & & \\
\hline $\begin{array}{c}\text { Not } \\
\text { Authoritarian }\end{array}$ & 5 & 13,9 & 5 & 13,9 & 10 & 27,8 & & \\
\hline Authoritarian & 8 & 22,2 & 18 & 50 & 26 & 75 & 0,05 & 0,085 \\
\hline Total & 13 & 36,1 & 23 & 63,9 & 36 & 100 & & \\
\hline
\end{tabular}

Based on it is known that out of 9 respondents who are not authoritarian parenting have a pretty good cooperative level of children amounting to $5(13.9 \%)$ and $5(13.9 \%)$ respondents who have a good cooperative level of children. While 26 (75\%) respondents were authoritarian parenting who had a pretty good cooperative level of children amounting to 8 respondents (22.2\%) and 18 $(52.8 \%)$ respondents who had a good cooperative level of children. The statistical test results obtained that the p-value is $0.058>0.05$ so that the null hypothesis (Ho) is accepted which means there is an influence of authoritarian parenting on the cooperative level of 305-year-old children in dental and oral care in Blang Karieng Village Nisam District 2017.

Table 8. The Effect of Permissive Parenting on the Cooperative Level of 3-5 Years Old Children in Dental and Oral Care in Blang Karieng Village, Nisam District, 2017. 


\begin{tabular}{|c|c|c|c|c|c|c|c|c|}
\hline \multirow{3}{*}{$\begin{array}{l}\text { Permissive } \\
\text { Parenting }\end{array}$} & \multicolumn{4}{|c|}{ Cooperative level of Children } & \multicolumn{2}{|c|}{ Total } & \multirow{3}{*}{$\begin{array}{c}\text { Va } \\
\text { lue } \\
\alpha\end{array}$} & \multirow{3}{*}{$\begin{array}{c}p \\
\text { value }\end{array}$} \\
\hline & \multicolumn{2}{|c|}{ Cukup baik } & \multicolumn{2}{|c|}{ Baik } & & & & \\
\hline & f & $\%$ & $\mathbf{f}$ & $\%$ & f & $\%$ & & \\
\hline $\begin{array}{l}\text { Not Permis } \\
\text { sive }\end{array}$ & 5 & 13,9 & 5 & 13,9 & 10 & 27,8 & & \\
\hline Permis sive & 8 & 22,2 & 18 & 50 & 26 & 75 & 0,05 & 0,085 \\
\hline Total & 13 & 36,1 & 23 & 63,9 & 36 & 100 & & \\
\hline
\end{tabular}

Based on the table it is known that out of 9 respondents who were not permissive parenting had a fairly good cooperative level of children amounting to $5(13.9 \%)$ and $5(13.9 \%)$ respondents who had a good cooperative level of children. While $26(75 \%)$ respondents were permissive parenting who had a pretty good cooperative level of children, amounting to 8 respondents (22.2\%) and $18(52.8 \%)$ respondents who had a good cooperative level of children. The statistical test results obtained that the p-value is $0.058>0.05$ so the null hypothesis (Ho) is accepted which means that there is an influence of permissive parenting on the cooperative level of 305 years old children in dental and oral care in Blang Karieng Village, Nisam District, 2017.

\section{Research Discussion}

\subsection{Effect of Democratic Care Patterns on the Cooperative Level of 3-5 Years Old Children in Dental and Oral Care in Blang Karieng Village Nisam District.}

Based on the results of data processing, it is known that from 9 respondents who were not Democratic parenting had a fairly good cooperative level of children amounting to 5 (13.9\%) and $4(11.1 \%)$ respondents who had good cooperative levels of children. While $27(75 \%)$ respondents who are quite good at parenting Democracy who have a pretty good level of cooperation amounted to 8 respondents $(22.2 \%)$ and $19(52.8 \%)$ respondents who have a good cooperative level. The statistical test results obtained that the p-value is $0.067>0.05$ so that the null hypothesis (Ho) is accepted which means there is a significant effect of the influence of Democratic parenting on the cooperative level of 305-year-old children in oral and dental care in Nisang Tahun Blang Karieng Village 2017 (Notoatmodjo, 2012).

In a study ever conducted by Wendy K. Lamont (2008) about the role of parenting in children it was also found that hard parents (muscles) were precisely the main determinants of behavioral problems for children. Harsh parents (muscles) are associated with a 50\% increase in risk for child behavior problems in dental and oral care.

Obtained a significance value for authoritarian parenting of 0.047 , this means that there is a significant effect of authoritarian parenting on the cooperative level of children aged 3-5 years 
studied. In addition, it shows that the influence of the parenting style on the cooperative level of children aged 3-5 years studied is 0.387 , this figure is quite low when compared to other parenting styles.

According to researchers' assumptions from the results of statistical tests with a p-value of $0.067>0.05$, it means that there is an influence of Democratic parenting on the cooperative level of 3-5 year olds in dental and oral care in Blang Karieng Village, Nisam District, 2017.

\section{B. Pengaruh Pola Asuh Otoriter terhadap Tingkat Kooperatif Anak Usia 3-5 Tahun dalam Perawatan Gigi dan Mulut di Desa Blang Karieng Kecamatan Nisam.}

Based on the results of data processing, it is known that out of 9 respondents who were not authoritarian parenting had a fairly good level of cooperative children, amounting to 5 (13.9\%) and $5(13.9 \%)$ respondents who had good cooperative levels of children. While $26(75 \%)$ respondents were authoritarian parenting who had a pretty good cooperative level of children amounting to 8 respondents $(22.2 \%)$ and $18(52.8 \%)$ respondents who had a good cooperative level of children. The statistical test results obtained that the $p$-value is $0.058>0.05$ so that the null hypothesis (Ho) is accepted which means there is an influence of authoritarian parenting on the cooperative level of 305-year-old children in dental and oral care in Blang Karieng Village Nisam District 2017.

These results relate to the results of data analysis in the Wendy K. Lamont study in 2008 about the role of parenting in children also found that hard parents (musclesriter) are precisely the main determinant of behavior problems for children. Harsh parents (muscles) are associated with a 50\% increase in risk for child behavior problems in dental and oral care.

Obtained a significance value for authoritarian parenting of 0.047 , this means that there is a significant effect of authoritarian parenting on the cooperative level of children aged 3-5 years studied. In addition, table V.17 also shows the influence of the muscle care pattern on the cooperative level of children aged 3-5 years studied is 0.387 , this figure includes a fairly low value when compared with other parenting styles.

According to the researchers' assumptions from the results of statistical tests with a p-value of $0.058>0.05$ so that the null hypothesis (Ho) is accepted which means there is an influence of authoritarian parenting on the cooperative level of 3-5 year olds in dental and oral care in Blang Karieng Subdistrict Village Nisam in 2017. 


\section{Effect of Permissive Care Patterns on the Cooperative Level of 3-5 Years Old Children in Dental and Oral Care in Blang Karieng Village Nisam District.}

Based on the results of data processing, it is known that out of 10 respondents who were not permissive parenting had a fairly good level of cooperative children, amounting to $5(13.9 \%)$ and $5(13.9 \%)$ respondents who had good cooperative levels of children. While $26(75 \%)$ respondents were authoritarian parenting who had a pretty good cooperative level of children amounting to 8 respondents $(22.2 \%)$ and $18(52.8 \%)$ respondents who had a good cooperative level of children. The statistical test results obtained that the p-value is $0.058>0.05$ so that the null hypothesis (Ho) is accepted which means there is an influence of permissive parenting on the cooperative level of 3-5 year olds in dental and oral care in Blang Karieng Village Nisam District 2017 .

The results of this study are supported by a study by Wendy K. Lamont regarding parenting in 2008, stating that permissive parenting can lead to aggressive children, not obedient to parents and less able to control themselves. Alev Onder and Hulya Gulay in 2009 also added that children with permissive parenting parents would make children impulsive, spoiled, less independent, self-interested, less confident and less socially mature.

From the results of hypothesis testing obtained a significance value of 0.037 , this means that there is a significant effect of permissive parenting on the cooperative level of children aged 3-5 years studied. In this table also shows exponent B for permissive parenting of 0.370 , this value is the smallest value among the other three parenting patterns. That is, parents with permissive parenting have greater potential to make children uncooperative in dental and oral care.

According to the researchers' assumptions from the results of statistical tests with a p-value of $0.058>0.05$ so that the null hypothesis (Ho) is accepted which means there is an influence of permissive parenting on the cooperative level of 3-5 year olds in dental and oral care in Blang Karieng Subdistrict Nisam in 2017.

\section{Research Conclusion}

1. The highest distribution of respondents based on gender is girls, amounting to 24 people (66.7\%), and boys totaling 12 people (33.3\%).

2. The distribution of respondents based on the age of the most is the most are children aged 4 years, amounting to 15 respondents $(41.7 \%)$.

3. The frequency distribution of the influence of democratic parenting on the cooperative level of children aged 3-5 years in dental care and stretching is in the Democratic 
category, amounting to 27 respondents $(75 \%)$ and those who are not Democratic there are 9 respondents $(25 \%)$.

4. The frequency distribution of the influence of authoritarian parenting on the cooperative level of 3-5-year-old children in dental care and stretching is in the authoritarian category, which amounted to 27 respondents (72.2\%) and non-authoritarian ones totaling 9 respondents $(27.8 \%)$.

5. The frequency distribution of the influence of permissive parenting on the cooperative level of 3-5 year olds in dental care and stretching is in the authoritarian category, which amounted to 27 respondents $(72.2 \%)$ and non-authoritarian ones totaling 9 respondents $(27.8 \%)$.

\section{Suggestion}

So that the results of this study can be used as useful information or input to students at Getsampena School of Health (STIKes) and parents who have pre-school children in increasing their knowledge of parenting for dental and oral care for children aged 3-5 year.

\section{REFERENCES}

[1] Achmad, IF. Lutfatul Latifah and Dewi Natalia Husadayant. 2010. Relationship between Parents' Care Patterns with Emotional Quotient in Preschool Children (3-5 Years) in AL-Fattah Sumampir Islamic Kindergarten North Purwikerto. Journal of Nursing in Sudirman. Volume 5, no. 1.

[2] Ambarwati, E.R and Diah Wulandari 2010. Nifas Midwifery Care. Yogyakarta: Nuha Medika.

[3] Ayesha, St. 2010. Effect of Parenting Parents Against the Level of Child Aggressiveness. Journal of Medtek. Vol. 2, No. 1.

[4] Arikunto, S. 2006. Research Procedure A Practice Approach. Revised Edition VI. Jakarta: Rineka Cipta.

[5] Habibi, M. (2007). Parental Guidance Program in Implementing Parenting Patterns to Improve Children's Social Maturity. Bandung: Indonesian education university.

[6] Christine, Alicia. 2009. Principles of Affection Raising Your Child. Terj. Triwahyuni. Jakarta: Pustakaraya.

[7] Christy, S.K. 2010. A Study To Assess The Effectiveness Of Structured Teaching Program On Sibling Rivalry And Its Prevention Among Mothers Of Underfive Children In A Selected Urban Area At Karnataka District India.

[8] Nisa, Zuhrotun. Lilis Maghfuroh and Supanik. 2010. Relationship between the Attitudes of the People and Sibling Rivalry in Toddler Ages in the village of Gendong Kulon Babat Lamongan. Vol. 3, No.7.

[9] Notoatmodjo, S (2010). Health Promotion and Behavioral Sciences. Jakarta: Rineka Cipta. 
[10] Notoatmodjo, S (2011). Health Behavior Sciences. Jakarta: Rineka Cipta.

[11] Notoatmodjo, S (2012). Health Research Methodology. Jakarta: Rineka Cipta.

[12] Pieter, HZ. and Namora Lumongga Lubis. 2010. Introduction to Psychology for Midwifery. First Edition. Jakarta: Kencana.

[13] Pramawaty, Nisha. And Elis Hartati. 2012. Relationship between Parents' Parenting Style and Self Concept of School-Age Children (10-12 Years). Nursing Student Journal. Volume1, No.1.

[14] Riyadi, Sujono. And Sukarmin. 2009. Nursing Care for Children. First Edition. Yogyakarta: Graha Ilmu.

[15] Sari, Meidia. 2012. Psychological Causes and Psychological Impacts of Sibling Competition on Students in One Boarding House. Vol. 2, No.1.

[16] Setiawati and Zulkaida Anita. 2007. Sibling rivalry at AnakSulung which is Parented by Single Father. Proceedings of the Defender.

[17] Soemardini. Rinik Eko Kap and Chika Juni Rachmawa. 2011. Relationship of the Role of Mothers with Sibling Levels of Rivalry in Preschool Children 3-5 Years in the Territory of Ketawanggede Malang.

[18] Septriati, B. 2012. Printing Smart Toddlers and Parenting Parents. Yogyakarta: Nuha Medika.

[19] Suharsono, J. T. Aris Fitriyani and Arif Setyo Upoyo. 2009. The Relationship of Parents' Parenting Patterns to Socialization Ability to Preschool Children at TKPertiwi North Purwokerto. Sudirman Nursing Journal (The Sudirman Journal of Nursing). Volume 4, No.3.

[20] Susanto, Ahmad. 2011. Development of Early Childhood, Introduction to Various Aspects. Jakarta: Kencana Prenada Media Group.

[21] Woolfson, Richard. 2004. Sibling Competition: Encouraging Children to Be Friends. Translation of Fransiscus Rudianjo. Jakarta: Erlangga.

[22] Yusuf A. St. Hajrah.2013. Effect of parenting parents on cooperative level of 3-5 years old in dental and oral care. 